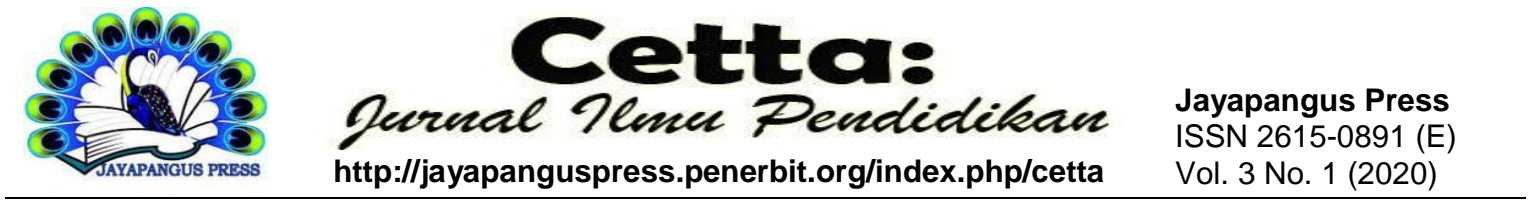

\title{
Pengembangan Media Pembelajaran Berbasis Android Pada Mata Kuliah Fisika Dasar
}

\author{
Novi Hendri Adi ${ }^{1}$, Atman Lucky Fernandes ${ }^{2}$, Hermansyah ${ }^{3}$ \\ Sekolah Tinggi Teknik Ibnu Sina \\ 1novihendriadi@gmail.com
}

DOI : $10.37329 /$ cetta.v3i1.414

\begin{tabular}{|c|c|}
\hline Keywords: & Abstract \\
\hline $\begin{array}{l}\text { Learning Media, } \\
\text { Android, Four-D, } \\
\text { Basic Physics. }\end{array}$ & $\begin{array}{l}\text { The aim of the research is to develop an Android-based learning media on } \\
\text { basic physics courses in informatics engineering at STT Ibnu Sina which } \\
\text { is valid, practical, effective. This study uses a method with Four-D } \\
\text { design applied to develop and test the validity, practicality and } \\
\text { effectiveness of android-based learning media. The stages of the research } \\
\text { include defining, designing, developing, and distributing. The results of } \\
\text { testing the validity of Android-based learning media indicate that the } \\
\text { learning media are valid. Based on the response oflecturers and students } \\
\text { about the practicality of instructional media shows that learning media } \\
\text { is very practical and based on student learning outcomes indicate that } \\
\text { the Android-based learning media has been effectively used in basic } \\
\text { physics learning. The results of data analysis show that Android-based } \\
\text { learning media is better in improving student learning in the basic } \\
\text { physics learning process. Then concluded that the Android-based } \\
\text { learning media can be applied in learning basic physics. Android-based } \\
\text { learning media can be developed more broadly along with technological } \\
\text { developments in the learning process. }\end{array}$ \\
\hline
\end{tabular}

\begin{tabular}{l} 
Kata Kunci: \\
\hline Media \\
Pembelajaran, \\
Android, 4-D, \\
Fisika Dasar.
\end{tabular}

Abstrak
Tujuan dari penelitian ini adalah untuk mengembangkan
media pembelajaran berbasis Android pada matakuliah fisika
dasar. Penelitian ini menggunakan metode dengan desain
Four-D yang diterapkan untuk mengembangkan dan menguji
validitas, kepraktisan dan efektivitas media pembelajaran
berbasis android. Tahapan penelitian termasuk
mendefinisikan, merancang, mengembangkan, dan
mendistribusikan. Hasil pengujian validitas media
pembelajaran berbasis Android menunjukkan bahwa media
pembelajaran tersebut valid. Berdasarkan tanggapan dosen
dan mahasiswa tentang kepraktisan media pembelajaran
menunjukkan bahwa media pembelajaran sangat praktis dan
berdasarkan hasil belajar siswa menunjukkan bahwa media
pembelajaran berbasis Android telah efektif digunakan dalam
pembelajaran fisika dasar. Hasil analisis data menunjukkan




bahwa media pembelajaran berbasis Android lebih baik dalam
meningkatkan pembelajaran siswa dalam proses pembelajaran
fisika dasar. Kemudian disimpulkan bahwa media
pembelajaran berbasis Android dapat diterapkan dalam
pembelajaran fisika dasar. Media pembelajaran berbasis
Android dapat dikembangkan secara lebih luas seiring dengan
perkembangan teknologi dalam proses pembelajaran.

\section{Pendahuluan}

Teknologi informasi dan komunikasi sangat berpengaruh dalam perkembangan pendidikan sehingga pembelajaran berbasis teknologi informasi sekarang ini merupakan keharusan. Teknologi pada era global seperti saat ini berkembang sangat cepat dan menyeluruh di semua kalangan dan bidang. Salah satu bidang yang tidak bisa terlepas dari teknologi adalah bidang pendidikan. Lembaga pendidikan dituntut untuk dapat adaptif terhadap perubahan paradigma pendidikan dari tradisional menuju teknologi informasi yang merupakan tuntutan masyarakat global. Pelaksanaan pendidikan tidak dapat terlepas dari perkembangan ilmu pengetahuan dan teknologi (IPTEK). Pada saat sekarang ini dikenal dengan budaya belajar abad 21, dimana pembelajaran tidak lagi terpusat pada guru namun pembelajaran terpusat pada siswa, dimana siswa dituntut lebih aktif mencari, memahami, dan menganalisis materi pelajaran dalam sebuah proses pembelajaran.

Selain itu, proses pembelajaran dilaksanakan dengan menggunakan metode dan media pembelajaran berbasis komputer atau berbasis Information and Communication Technology (ICT) yang lebih interaktif dan menarik, tidak lagi hanya menggunakan media pembelajaran presentasi sederhana terutama untuk materi pembelajaran yang bersifat abstrak tetapi sudah menggunkan teknologi komputer dan mobile. Penggunaan media pembelajaran merupakan bagian yang tidak bisa dipisahkan dan sudah merupakan suatu integrasi terhadap metode belajar yang dipakai (Kuswanto, 2018). Pada Matakuliah Fisika Dasar merupakan salah satu matakuliah wajib yang harus diikuti oleh mahasiswa, bertujuan untuk menjelasakan konsep memakai berbagai formulasi fisika untuk memecahkan masalah fisika sederhana penerapannya.

Materi pelajaran fisika dasar banyak berupa penjelasan konsep yang bersifat abstrak yang sulit dijelaskan oleh para dosen dan dipahami oleh mahasiswa jika hanya menggunakan media pembelajaran presentasi sederhana, dibutuhkan media pembelajaran yang benar-benar mampu mengkongkretkan hal yang bersifat abstrak 
sehingga mudah dipahami oleh mahasiswa, sebagai contoh, materi fisika dasar membahas tentang listrik statis dan dinamais, selain itu, materi fisika dasar juga terdapat beberapa istilah sulit yang bersifat abstrak seperti pengertian dan bentuk arus listrik, tegangan, dan resistansi. Materi pelajaran seperti ini dalam penyampaiannya dan pemahamannya membutuhkan media yang mampu menjelaskannya secara kongkret dengan menampilkan berupa gambar bergerak (animasi) yang menarik. Dengan demikian, dapat diketahui bahwa untuk mata kuliah fisika dasar ini dibutuhkan media pembelajaran yang dapat menjelaskan secara kongkret agar dapat membantu dosen dalam menjelaskan materi pembelajaran.

Berdasarkan kenyataan tersebut, maka perlu dicari alternatif lain dengan melakukan inovasi dan pendekatan dalam penggunaan media pembelajaran yang efektif, dan adaptif dengan kemajuan teknologi serta mampu mendukung aktivitas belajar untuk penyampaian materi kepada mahasisswa pada saat berlangsungnya proses pembelajaran di kelas. Dengan demikian proses pembelajaran dapat berlangsung aktif, inovatif, kreatif, efektif, dan menyenangkan yang pada akhirnya, hasil belajar siswa meningkat. Farida Hasan Rahmaibu (2016) “Pengembangan Media Pembelajaran Menggunakan Adobe Flash untuk meningkatkan Hasil Belajar" metode digunakan peneliti adalah metode penelitian dan pengembangan (Researchand Development). Hasil dari pengujian system ini dapat penunjukan bahwa sebuah media dapat mengembangkan, kelayakan, dan membandingkan perbedaan dalam hasil pembelajaran sebelum dan sesudah menggunakan multimedia berbasis Adobe Flash pada pembelajaran Pendidikan Kewarganegaraan tentang konten Globalisas di kelas 4B Madrasah Ibrani Al Madina Semarang.

Anwar Efendi (2018) Pengembangan Media Pembelajaran berbasis Video Tutorial Pada Mata kuliah Mekanika Tanah. Metode yang dipakai oleh peneliti adalah metode penelitian dan pengembangan (Research and Depelopment). Hasil penelitian Menunjukkan bahwa tersusunnya media pembelajaran berbasis video tutorial pada mata kuliah mekanika tanah dengan tingkat kelayakan berdasarkan penilaian ahli materi diperoleh persentase sebesar 79,58 \% termasuk kategori layak, penilaian ahli media diperoleh persentase sebesar77,5\% termasuk kategori layak, penilaian ahli persentase sebesar 75, 867\% termasuk kategori layak pembelajaran dengan persentase sebesar 86,13 $\%$ termasuk kategori sangat layak. Hasil uji coba terbatas hasil yang diperoleh persentase sebesar 86,13\% termasuk kategori sangat layak. 
Arda (2015) “Pengembangan Media Pembelajaran Berbasis Komputer untuk Siswa SMP Kelas VIII. Penelitian ini merupakan penelitian pengembangan (research and development). Pengembangan Media pembelajaran interaktif ini dikemas dalam bentuk compact disc (CD) dengan menggunakan program macromedia flash 8. Dari kajian literatur dapat disimpulkan bahwa belum ada penelitian yang dilakukan di STT Ibnu Sina. Pembelajaran mengalami perpindahan yang semula konvensional menjadi ELearning (Listyorini, 2013). Dengan demikian maka perlu dilakukan penelitian "Pengembangan Media Pembelajaran Berbasis Android pada Matakuliah Fisika Dasar. Walaupun selama ini pembelajaran mata kuliah fisika sudah memanfaatkan teknologi, tetapi belum pemanfaatan ini belum optimal (Kurniawati, 2018). Tujuan dari penelitian ini adalah untuk pengembangkan media pembelajaran berbasis android pada matakuliah fisika dasar dan mengetahui validitas, praktikalitas, dan efektivitas media berbasis android.

\section{Metode}

Penelitian ini adalah penelitian pengembangan (Research and Development), hal ini berdasarkan pada rumusan masalah dan tujuan penelitian yang akan dicapai. Dalam penelitian pengembangan ini produk yang dihasilkan adalah berupa media pembelajaran. Penelitian pengembangan ini dipilih karena penelitian pengembangan merupakan penelitian yang digunakan atau dilakukan untuk menghasilkan produk tertentu serta menguji efektivitas dari produk yang dibuat dan dikembangkan tersebut. Penelitian analisis kebutuhan dibutuhkan untuk dapat menghasilkan produk tertentu dan untuk menguji efektivitas produk yang dihasilkan tersebut supaya dapat berfungsi pada masyarakat luas, maka diperlukan penelitian untuk menguji efektivitas produk tersebut. Model pengembangan yang dipilih dalam penelitian ini adalah model 4-D (four-D) karena model pengembangan tersebut mempunyai prosedur yang sistematis, sesuai dengan latar belakang masalah, rumusan masalah dan tujuan penelitian yang akan dicapai.

Thiagarajan (dalam Trianto, 2009:189) mengemukakan bahwa proses pengembangan dengan model Four-D terdiri dari 4 tahap utama yaitu: (1) Tahap Pendefinisian (Define Phase) ini bertujuan untuk memunculkan dan menetapkan masalah dasar yang dihadapi dalam pembelajaran, sehingga diperlukan suatu pengembangan bahan ajar, (2) Tahap Perancangan (Design Phase) hasil analisis dari tahap pendefinisian 
akan digunakan untuk tahap selanjutnya yaitu tahap perancangan, (3) Tahap Pengembangan (Develop Phase) tahap pengembangan bertujuan untuk menghasilkan media pembelajaran yang valid, praktis, dan efektif, (4) tahap Penyebaran (Dissaminate Phase) merupakan suatu tahap akhir pengembangan. Tahap diseminasi dilakukan untuk mempromosikan produk pengembangan agar bisa diterima oleh pengguna, baik individu, suatu kelompok maupun sistem. Diseminasi bisa dilakukan dikelas lain dengan tujuan untuk mengetahui efektivitas penggunaan perangkat dalam proses pembelajaran pada kelas lain. Bentuk desiminasi ini dilaksanakan dengan tujuan untuk mendapatkan masukan, saran, penilaian melalui lembar observasi untuk menyempurnakan produk akhir pengembangan agar siap diadopsi oleh para pengguna produk.

\section{Hasil dan Pembahasan}

\section{Hasil Penelitian}

\section{a. Tahap Pendefinisian}

Tahap pendefinisian ini dilakukan untuk mendapatkan gambaran kondisi di lapangan terkait dengan proses pembelajaran fisika dasar pada prodi Teknik Informatika. Pada tahap ini ada tiga hal yang dilakukan yaitu observasi, analisis kurikulum dan analisis mahasiswa.

\section{b. Tahap Pencangan}

Pada tahap ini dilakukan penyusunan kerangka dalam media pembelajaran berbasis android berupa desain tampilan media yang meliputi halaman pembuka, halaman home yang merupakan menu utama dari media, ada beberapa menu yang disediakan pada halaman menu utama yaitu, 1) halaman utama 2) tampilan menu RPS 3) menu materi yang berisi materi pembelajaran fisika dasar 4) menu kuis yang berisi soal objektif untuk mengevaluasi proses pembelajaran 5) menu profil yang berisi profil pembuat dan pengembang media.

\section{c. Tahap Pengembangan}

Pada tahap perancangan selesai, maka tahap selanjutnya adalah tahap pengembangan. Tahap pengembangan ini bertujuan untuk menghasilkan media pembelajaran interaktif yang valid, praktis dan efektif. Tahap pengembangan ini terdiri dari penilaian validasi media dan materi oleh validator dan penilaian praktikalitas oleh dosen dan mahasiswa. Serta pada bagian akhir dilakukan tes untuk mengetahui tingkat efektivitas media pembelajaran berbasis android yang dikembangkan. 
Tabel 1 Hasil Validasi Media dan Materi

\begin{tabular}{|l|l|l|l|l|}
\hline No. & Validator & Hasil & Kategori & Ket. \\
\hline 1 & Validator 1 & 0,77 & Media & Valid \\
\hline 2 & Validator 2 & 0,83 & Media & Valid \\
\hline 3 & Validator 3 & 0,88 & Materi & Valid \\
\hline 4 & Validator 4 & 0,85 & Materi & Valid \\
\hline
\end{tabular}

Untuk keterangan valid dan tidak valid menurut (Azwar S, 2014:112) dengan range nilai 0-1,00 dinyatkan valid dan $<0$ dinyatakan tidak valid. Dari tabel 1 dapat dilihat dari hasil validator 1, validator 2 untuk validasi media yaitu 0,82 dan 0,86, maka kedua validator menyatakan "Valid" untuk validitas media, dan validator 3, validator 4 untuk validasi materi yaitu 0,88 dan 0,85 , makan kedua validator menyatakan "valid" untuk vliditas materi.

Tabel 2 Hasil Praktikalitas Respon Dosen.

\begin{tabular}{|c|c|c|c|c|c|}
\hline \multirow{2}{*}{ No } & \multirow{2}{*}{ Penilaian } & \multicolumn{3}{|c|}{ Persentase penlaian } & \multirow{2}{*}{ Ket. } \\
\hline & & D1 & D2 & Rata2 & \\
\hline 1 & Teknis & 23 & 23 & \multirow{4}{*}{85,5} & Sangat Praktis \\
\hline 2 & Isi & 21 & 24 & & Sangat Praktis \\
\hline 3 & Desain & 41 & 39 & & Sangat Praktis \\
\hline \multicolumn{2}{|c|}{ Rata-Rata } & 85 & 85 & & Sangat Praktis \\
\hline
\end{tabular}

Berdasarkan tabel diatas terlihat bahwa ada tiga aspek praktikaltas media pembelajaran berbasis android berdasarkan respon dosen melalui angket. Persentase ratarata merupakan penilaian dari dosen 1 dengan nilai rata-rata $85 \%$ dari aspek teknis, isi dan desain. Kemudian respon dosen 2 dengan nilai rata-rata $85 \%$ dari aspek teknis, isi dan desain, dengan menggabungkan kedua respon dari dosen tersebut memperoleh ratarata yaitu sebesar $85.5 \%$ degan kategori sangat praktis.

Tabel 3 Praktikalitas Respon Mahasiswa

\begin{tabular}{|l|l|c|l|}
\hline No & \multicolumn{1}{|c|}{ Penilaian } & Persentase Penilaian & Kategori \\
\hline 1 & Kemudahan & 85 & Sangat Praktis \\
\hline 2 & Motivasi & 84 & Sangat Praktis \\
\hline 3 & Kemenarikan & 87 & Sangat Praktis \\
\hline 4 & Kebermanfaatan & 88 & Sangat Praktis \\
\hline \multicolumn{2}{|l|}{ Rata-rata } & 86 & Sangat Praktis \\
\hline
\end{tabular}

Berdasarkan hasil analisis data praktikalitas melalui respon mahasiswa maka didapatkan nilai praktikalitas sebesar $86 \%$ yang apabila di interprestasikan dengan taraf kepraktisan maka tingkat praktikalitas media pembelajaran berbasis android pada mata 
kuliah fisika dasar berada pada taraf sangat prkatis. Dengan demikian dapat disimpulkan bahwa media pembelajaran berbasis android pada mata kuliah fisika dasar ini sangat praktis digunakan oleh mahasiswa dalam proses pembelajaran. Hasil uji efektifits dapat dilihat dari hasil belajar mahasiswa. Kemudian dilakukan uji normalitas, homogenitas dan uji t.

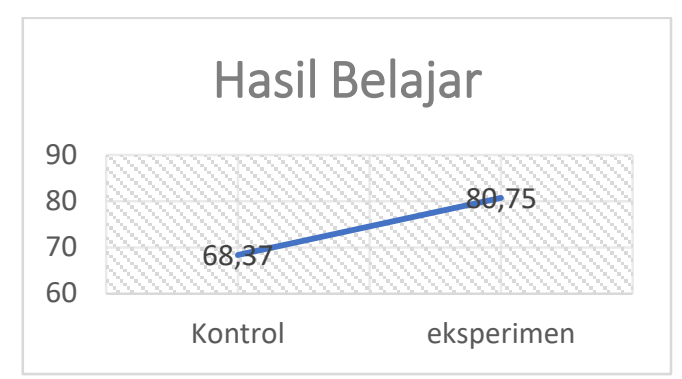

Gambar 1 Hasil Belajar mahasiswa

Hasil belajar mahasiswa (postest) kelas kontrol (kelas tidak menggunakan media pembelajaran) dan kelas eksperiment (menggunakan media pembelajaran). Hasil belajar kelas kontrol dari 32 orang mahaiswa didapat hasil untuk postest $(68,37)$, dan hasil belajar kelas eksperiment dari 32 orang mahasiswa didapat hasil untuk postest $(80,75)$. Dari hasil uji normalitas yang telah dilakukan dengan SPSS didapati nilai sebagai berikut

Tests of Normality

\begin{tabular}{|c|c|c|c|c|c|c|c|}
\hline & \multirow[b]{2}{*}{ kelas } & \multicolumn{3}{|c|}{ Kolmogorov-Smirnov ${ }^{\mathrm{a}}$} & \multicolumn{3}{|c|}{ Shapiro-Wilk } \\
\hline & & Statistic & df & Sig. & Statistic & $d f$ & Sig. \\
\hline \multirow[t]{2}{*}{ hasil } & kontrol & .110 & 32 & $.200^{\circ}$ & .979 & 32 & .773 \\
\hline & eksperimen & .149 & 32 & .067 & .936 & 32 & .058 \\
\hline
\end{tabular}

Gambar 2 Hasil Uji Normalitas

Dari gambar 2 didapat nilai signifikan untuk kelas kontrol sebesar 0,200 dan untuk kelas eksperimen sebesar 0,067, jadi dapat disimpulkan bahwa data berdistribusi normal karena > 0,05. Hasil Uji Homogenitas hasil belajar kelas kontrol dan eksperimen dapat dilihat pada gambar berikut;

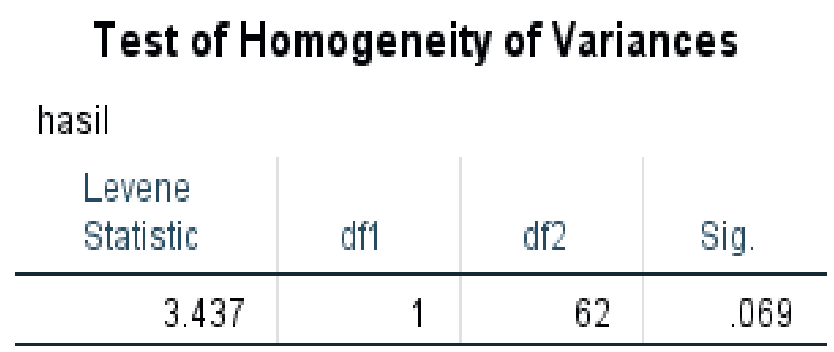

Gambar 3 Hasil Uji Homogenitas 
Dari gambar 3 dapat dilihat nilai signifikan sebesar 0.069 lebih besar dari 0,05 sehinggga dapat disimpulkan bahwa antara kelas kontrol dan eksperimen mempunyai varians homogen. Berdasarkan uji normalitas dan homogenitas varian posttest didapat bahwa kedua kelas terdistribusi normal dan mempunyai varian yang homogen, sehingga uji perbedaan dua rata-rata kelas, berikut hasil uji t:

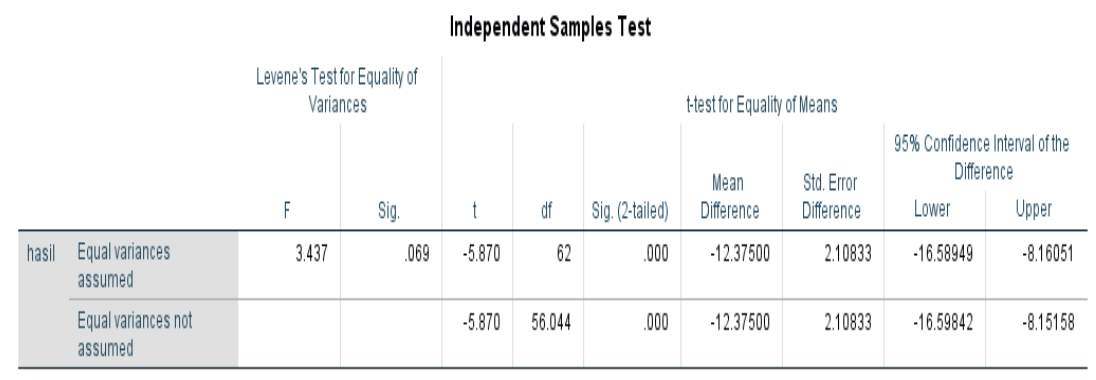

Gambar 4 Hasil Uji t

Dari gambar 4 terlihat nilai signifikan sebesar 0,000 lebih kecil dari 0,05 sehingga dapat disimpulkan bahwa adanya perbedaan yang signifikan antara kelas kontrol dan eksperimen

\section{d. Tahap Penyebaran}

Media pembelajaran berbasis android pada mata kulia fisika yang telah dikembangkan merupakan pembelajaran yang valid, praktis dan efektif. Kesimpulan ini didapat dari hasil uji validitas, praktikalitas, dan efektivitas media pada tahap pengembangan. Kemudian media pembelajaran ini disebarkan pada mahasiswa yang mengambil mata kuliah fisika dasar. Tahap penyebaran ini dilakukan dengan tujuan untuk mengetahui keterlaksanaan penggunaan media pembelajaran berbasis android dengan melihat aktivitas belajar mahasiswa selama menggunakan media pembelaran dalam proses pembelajaran. Data diperoleh dari pengamatan aktivitas belajar mahasiswa yang diamati oleh observer sebagai berikut.

Tabel 4 Hasil Observasi aktifitas Belajar

\begin{tabular}{|l|l|c|}
\hline No & \multicolumn{1}{|c|}{ Aspek Penilaian } & Persentase \\
\hline 1 & Mengikuti pelajaran & 90,6 \\
\hline 2 & $\begin{array}{l}\text { Memperhatikan dan mengoperasikan media Pembelajaran } \\
\text { berbasis android }\end{array}$ & 84,3 \\
\hline 3 & Mendengarkan penjelasan dosen & 78,1 \\
\hline 4 & Tidak rebut & 75 \\
\hline 5 & Merespon pertanyaan dosen atau mahasiswa & 75 \\
\hline 6 & Berdiskusi dengan teman & 81,2 \\
\hline 7 & Menyimpulkan materi & 78,1 \\
\hline \multicolumn{2}{|l|}{ Rata-Rata } & 80 \\
\hline
\end{tabular}




\section{Pembahasan}

Pengembangan media pembelajaran berbasis android pada matakuliah fisika dasar dirancang sesuai dengan kebutuhan dan permasalahan dalam penelitian, pada tahap ini peneliti menyusun program terperinci yang meliputi semua komponen media pembelajaran berbasis android. Media pembelajaran berbasis android ini dilengkapi dengan gambar animasi, sound, teks, tombol navigasi sehingga lebih menarik dan memunculkan interaksi antara media pembelajaran dengan orang yang menggunakannya. Media pembelajaran berbasis android ini dirancang sesuai dengan materi pembelajaran fisika dasar.

Media pembelajaran berbasis android pada mata kuliah fisika dasae ini dikembangkan dengan menggunakan model pengembangan 4-D (Define, Desain, Develop, Disseminate), dengan harapan setelah dilakukan pengembangan ini, maka akan didapatkan media pembelajaran interaktif yang valid, praktis, dan efektif. Dalam proses pengembangan perlu dilakukan validasi, uji praktikalitas dan uji efektifitas. Tujuan dari validasi oleh ahli adalah untuk memperoleh masukan, kritik, dan saran perbaikan untuk kesempurnaan media yang dikembangkan. Data uji validasi diperoleh melalui instrumen validasi yang diisi oleh beberapa orang validator yang merupakan ahli media pembelajaran dan ahli materi. Validator terdiri dari 4 orang yaitu dua orang untuk validator media dan 2 orang untuk validator materi. Validasi ahli media difokuskan pada tampilan atau penyajian yang dilihat dari sudut pandang media. Validasi oleh ahli media bertujuan agar produk media pembelajaran berbasis android yang dikembangkan menjadi produk yang berkualitas secara aspek pemograman dan tampilan.

Data dari validator di peroleh dari angket yang telah diberikan penilaian oleh dua orang validator. Berdasarkan hasil analisis validitas diketahui bahwa media berbasis android pada mata lulia fisika dasar ini valid. Hasil lavidasi dari validator 1, validator 2 untuk validasi media yaitu 0,82 dan 0,86, maka kedua validator menyatakan "Valid" dan hasil validator 3, validator 4 untuk validasi materi yaitu 0,88 dan 0,85, makan kedua validator menyatakan "valid" untuk validitas materi. Saran dan penilaian dari validator dijadikan sebagai acuan untuk melakukan revisi terhadap media pembelajaran berbasis android ini. berdasarkan hasil analisis validitas dan revisi terhadap media pemebelajaran ini, kemudian didukung oleh hasil penelitian-penelitian yang telah dilakukan sebelumnya maka media pembelajaran berbasis android pada mata kuliah fisika dasar ini layak untuk diujicoba di lapangan. 
Data kepraktisan media pembelajaran bebrbasis android diambil melalui hasil pengisian angket kepraktisan yang dilaksanakan di STT Ibnu Sina ada prodi Teknik informatika yang mengambil mata kuliah fisika dasar. Untuk melihat kepraktisan, media pembelajaran berbasis android yang valid kemudian digunakan oleh dosen dan mahasiswa sebagai media pembelajaran dalam proses pembelajaran. Di akhir pembelajaran, dosen dan mahasiswa diminta mengisi angket kepraktisan dari media pembelajaran berbasis android yang telah digunakan. Penilaian terhadap kepraktisan media pembelajaran berbasis android ini diperoleh dari angket yang diisi oleh dosen dan hasil penilaian yang diperoleh dari angket respon dosen terhadap praktikalitas adalah sebesar 85,5 \% dengan kategori kepraktisan sangat praktis. Selain penilaian dari dosen, kepraktisan media pembelajaran berbasis android ini juga dinilai berdasarkan tanggapan mahasiswa dan hasil diketahui pada angket respon mahasiswa yaitu diperoleh nilai sebesar $86 \%$ dengan kategori sangat praktis. Sehingga dapat disimpulkan bahwa media pembelajaran berbasis android yang dikembangkan praktis digunakan oleh dosen dan mahasiswa pada proses pembelajaran.

Keefektifan media pembelajaran berbasis android dapat dilihat dari hasil belajar mahasiswa (posttest). Sebelum tes diberikan kepada kelas sampel, terlebih dahulu dilakukan ujicoba untuk mengetahui validitas, reliabilitas, tingkat kesukaran soal dan daya pembeda. Ujicoba soal dilakukan kepada kelas di luar sampel yang sama mengambil mata kuliah fisika dasar. Dari 30 soal yang di ujicobakan terdapat 20 soal yang dinyatakan valid dan 10 soal dinyatakan tidak valid. Kemudian dilakukan uji reliabilitas dengan mendapatkan hasil "reliabel". Untuk indek kesukaran terdapat 2 soal yang tergolong "sedang" dan 28 soal tergolong "mudah", dan uji daya beda diperoleh bahwa 3 soal kategori baik, 20 soal kategori cukup, dan 18 soal kategori jelek. Untuk hasil belajar mahasiswa, setelah dilakukan ujicoba soal maka posttest dilakukan pada dua kelas. Pertama kelas kontrol yang tidak menggunakan media pembelaaran berbasis android dari 32 orang mahaiswa didapat hasil untuk postest 68,37 , dan kedua hasil belajar untuk kelas eksperimen dengan menggunakan media pembelajaran berbasis android dari 32 orang mahasiswa didapat hasil untuk postest 80,75. Kemudian untuk soal posttest juga terdistribusi normal dengan nilai signifikan untuk kelas kontrol sebesar 0,200 dan untuk kelas eksperimen sebesar 0,067 dengan kaidah nilai tersebut $>0,05$. Soal posttest yang digunakan juga memiliki varian yang homogen dan memiliki perbedaan yang signifikan antara kelas kontrol dan eksperimen pada saat dilakukan uji t. 
Efektifnya media pembelajaran berbasis android ditentukan dengan cara mengetahui perbedaan hasil belajar mahasiswa kelas kontrol dan ekperimen. Perbedaan yang dimaksud adalah selisih antara hasil belajar kelas kontrol dan kelas ekperimen, apabila peningkatan hasil belajar mahasiswa kelas ekperimen lebih tinggi daripada kelas kontrol maka media pembelajaran berbasis android dapat dikatakan efektif. Hasil dari uji efektifitas menunjukan bahwa kelas eksperimen mendapatkan nilai lebih tinggi dibandingakan dengan kelas control, hal ini menunjukkan bahwa media pembelajaran berbasis android pada mata kuliah fisika dasar efektif digunakan dalam pembelajaran

\section{Kesimpulan}

Dari penelitian yang telah dilaksanakan, dapat disimpulkan bahwa hasil penelitian pengembangan media pembelajaran berbasis android pada mata kuliah fisika dasar Teknik informatika adalah proses pengembangan media pembelajaran yang mengacu pada model pengembangan 4-D yaitu Define (Pendefinisian), Design (Perancangan), Develop (Pengembangan), dan Dessiminate (Penyebaran). Penelitian pengembangan media pembelajaran berbasis android pada mata kuliaih fisika dasar prodi Teknik informatika ini menghasilkan penelitian yang valid, praktis dan efektif. Hal ini dibuktikan karena media pembelajaran ini telah mengalami uji coba validitas, praktikalitas dan efektifitas yang dilakukan terhadap validator, dosen dan mahasiswa.

\section{Daftar Pustaka}

Angin, T. B. B., \& Syahrul, R. (2015). Pengembangan Modul Berbasis Pendekatan Konstektual pada Materi Menulis Iklan di Kelas VIII SMP 2 Padangsidimpuan Sumatera Utara. Bahasa, Sastra, Dan Pembelajaran, 3(1).

Arda, A. (2015). Pengembangan media pembelajaran interaktif berbasis komputer untuk siswa SMP Kelas VIII. Mitra Sains, 3(1).

Azwar, S. (2014). Metode Penelitian Kuantitatif \& Kualitatif. Yogyakarta: Pustaka Pelajar.

Efendi, A., Sumarni, S., \& Efendi, A. (2015). Pengembangan Media Pembelajaran Berbasis Video Tutorial Pada Mata Kuliah mekanika Tanah. Indonesian Journal Of Civil Engineering Education, 1(1).

Kurniawati, I. D., \& Nita, S.-. (2018). Media Pembelajaran Berbasis Multimedia Interaktif Untuk Meningkatkan Pemahaman Konsep Mahasiswa. Doubleclick: Journal of Computer and Information Technology.https:// doi.org/10.25273/doubleclick.v1i2.1540 
Kuswanto, J., \& Radiansah, F. (2018). Media Pembelajaran Berbasis Android Pada Mata Pelajaran Sistem Operasi Jaringan Kelas XI. An Nabighoh Jurnal Pendidikan dan Pembelajaran Bahasa Arab. https:// doi.org/10.32332/an-nabighoh.v20i01.1131

Listyorini, T., \& Widodo, A. (2013). Perancangan Mobile Learning Mata Kuliah Sistem Operasi Berbasis Android. Simetris : Jurnal Teknik Mesin, Elektro dan Ilmu Komputer. https://doi.org/10.24176/simet.v3i1.85.

Rahmaibu, F. H. (2016). Pengembangan Media Pembelajaran Berbasis Multimedia Dengan Menggunakan Adobe Flash Untuk Meningkatkan Hasil Belajar Pkn Studi Kasus: di Al Madina Semarang. Universitas Negeri Semarang. 